Portland State University

PDXScholar

The history of community theatre in Anchorage, Alaska, 1946-1976

\title{
Robert Pond
}

Portland State University

Follow this and additional works at: https://pdxscholar.library.pdx.edu/open_access_etds

Part of the Theatre History Commons

\section{Let us know how access to this document benefits you.}

\section{Recommended Citation}

Pond, Robert, "The history of community theatre in Anchorage, Alaska, 1946-1976" (1980). Dissertations and Theses. Paper 2977.

https://doi.org/10.15760/etd.2970

This Thesis is brought to you for free and open access. It has been accepted for inclusion in Dissertations and Theses by an authorized administrator of PDXScholar. Please contact us if we can make this document more accessible: pdxscholar@pdx.edu. 
AN ABSTRACT OF THE THESIS OF Robert Pond for the laster of Arts in Theater Arts presented May 9, 1980.

Title: The History of Community Theatre in Anchorage, Alaska from 1946 to 1976.

APPROVED BY MEMBERS OF THE THESIS COMITTEE:

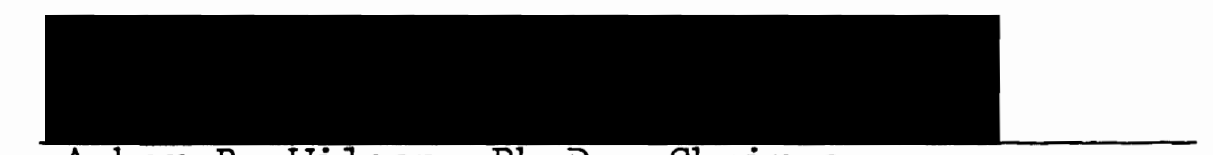

Asher B. Wilson, Ph.D., Chairman

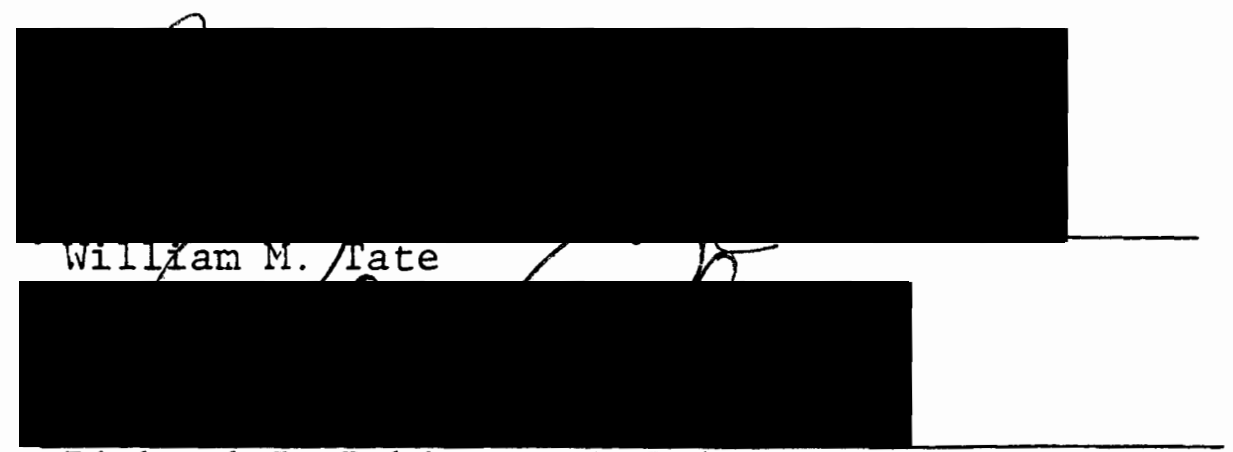

Richard J. Robinson, D.B.A.

PROBLEM:

This investigation sets forth the history of community theatre in Anchorage, Alaska and proposes to lefine a future role direction made necessary with the advent of professional theatre in the community.

By 1976 the Community Theatre movement in Anchorage found itself in direct competition with the professional performing programs for the limited performing space, subsidies, and audience. For the Community Theatre to continue functioning, a re-definition of non-professional theatre in 
Anchorage had to be found.

DATA :

The material data contributing to this research was largely tape recorded interviews with many of the persons involved with the development of Anchorage Commity Arts. Newspaper articles and reviews along with production playbills and scrapbooks were other source materials for this research. The tape recorded interviews were obtained between 1973 and 1979. The playbilis were borrowed and the newspaper items researched in the Municipality of Anchorage libraries and at the University of Alaska, Anchorage.

CONCLUSION :

It is the conclusion of this paper that a semi-professional structure would permit Community Theatre in Anchorage to both co-exist with the professional programs and serve the needs of the non-professional talents in the commity. In adopting the semi-professional direction, the Community Theatre develops a professional management while its performers remain non-professional participants from the community. 


\title{
THE HISTORY OF COMMUINITY
}

THEATRE IN ANCHORAGE, ALASKA

$$
1946-1976
$$

by

ROBERT POND

A thesis submitted in partial fulfillment of the requirements for the degree of

\author{
MASTER OF ARTS \\ in \\ THEATER ARTS
}

Portland State University

1980 
TO THE OFFICE OF GRADUATE STUDIES AND RESEARCH:

The members of the Cormittee approved the thesis Robert Pond presented May 9, 1980.
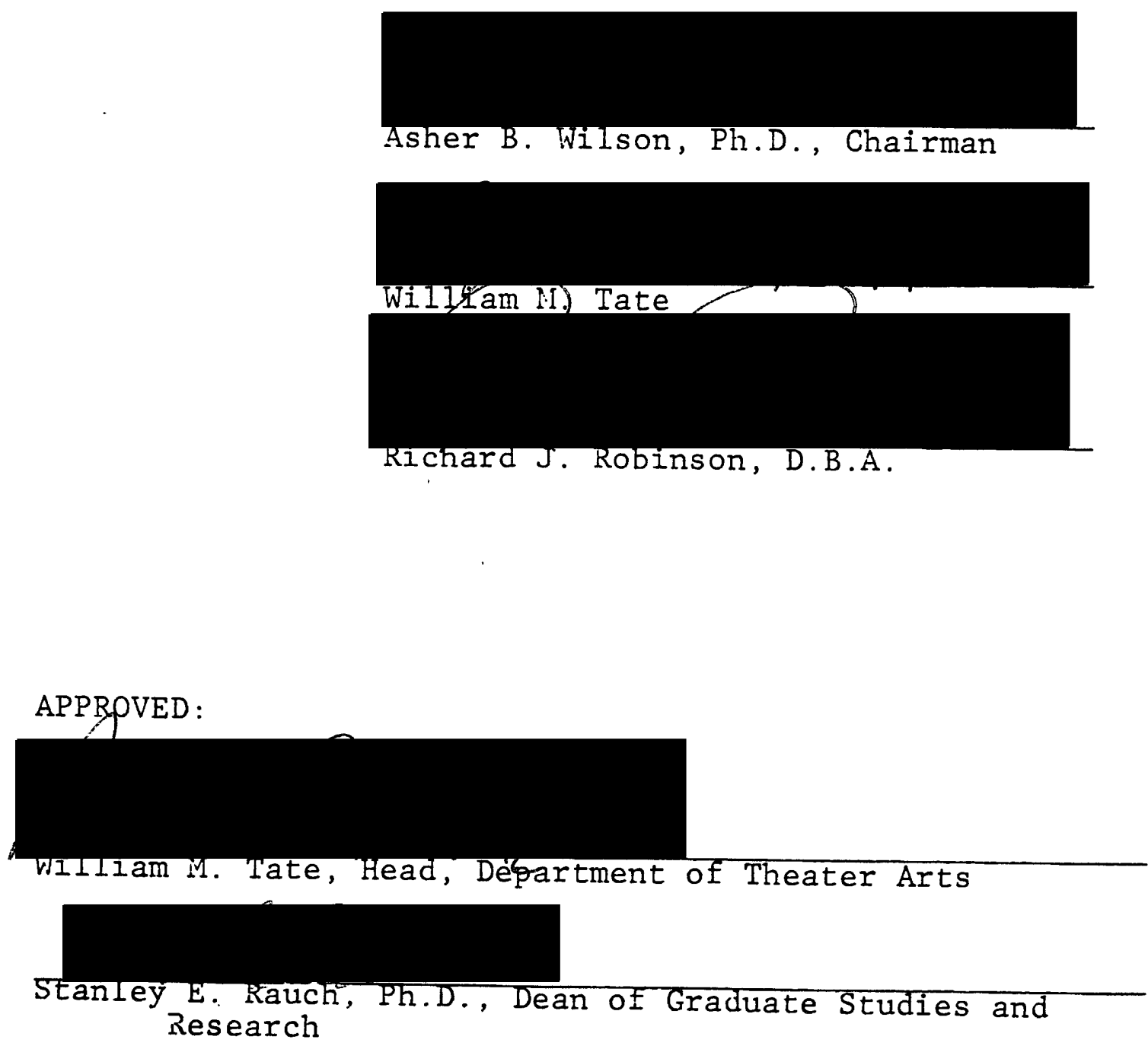
TABLE OF CONTENTS

PAGE

GENEOLOGY OF ANCHORAGE THEATRE............ iv

\section{CHAPTER}

I INTRODUCTION. ................. 1

II COMMUNITY THEATRE ESTABLISHED.......... 3 1946 - 1952

III THEATRE GROUPS BLOSSOM.............. 19 $1953-1960$

IV ANCHORAGE THEATRE IN TRANSITION......... 44 1961 - 1976

v CONCLUSION.................... 62

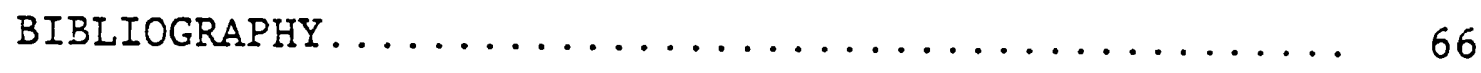


ROOTS OF THEAIRE IN: ANCHORAGE

1946 IHE ANCHORAGE IITTLE TTEATRE $(1946-63)$

$1953 \frac{\text { ALASKA COMM.THR. (1953) }}{1954}$

1955 ANCH. DRAMA LAB (1955-63)

1959

1959

ANCH. COMM. THR . (1959---)

1961 A.Y.U.DRAMA DEPT. $(1961-76)$

1963

T.0.5.S. $(1963-77)$

1964

CARNIVAL CIVIC THR. (1964-74)

1966

BOB BA.TKS THR PROD. (2966)

1968 A.C.T.GIIID $(2968-72)$

1972

1976

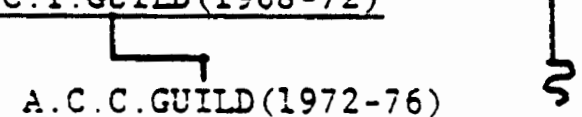

ELYE:TDORF TFR.GUIID (2955-63)

FI.RICH.TIR GUIID (1959)

1976 UA.A.IHR.DEPT. (1976---)

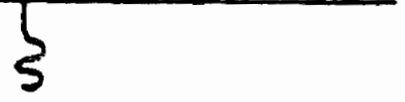

1979

$\frac{\text { A.P.U.DRAMA DEPT. (1979---) }}{\text { (EORMEIY A.M.U.) }}$ $\zeta$

$\frac{\text { ALASKA REPERTCRY THR (19,6---) }}{\text { (a professional thI companY) }}$

3 


\section{CHAPTER I}

\section{INTRODUCTION}

The community theatre movement is a unique alternative for those persons interested in theatre production though not as a career. Many people in the community have need for selfexpression and a diversion from their career responsibilities. Community theatre to a large degree meets this need. This investigation sets forth the history of community theatre in Anchorage, Alaska and proposes to define a future role and direction made necessary with the advent of professional theatre in the community.

In order to examine which direction the community theatre is to adopt in the future, it is necessary to reveal a historical development of theatre in Anchorage during the three decades that brought theatre to 1976 and the introduction of professional performing arts in Alaska. This paper shows the history of theatre in Anchorage in three sections, the establishment of community theatre in Anchorage (19461952), the proliferation of theatre groups (1953-i960), and the fifteen-year period that brought Anchorage theatre to 1976 and a time of significant change.

In tracing the history of the Anchorage theatre the intent was to examine the leaderships, the funding, and the constant search for facilities to better demonstrate the 
position of community theatre in Anchorage in the midseventies.

The proposition here is not whether community theatre should continue to exist, but rather how it can continue to function with and for the community while remaining a nonprofessional performing program, particularly, in the wake of the professional performing arts programs in Anchorage, Alaska. 


\section{CHAPTER II}

\section{COMMUNITY THEATRE ESTABLISHED}

$$
1946-1952
$$

The earliest evidence of non-musical dramatics in Anchorage seems to go back to Gertrude Mulcahy in the mid1920's. Besides teaching dance to children, Mrs. Mulcahy was very active in the teaching of dramatics or, more accurately, elocution. Likewise, during 1928 and 1929 Maurice Sharpe, a chemjst with the Alaska Railroad, was instrumental in producing a few short plays in Anchorage. The plays were presented occasionally and were not, seemingly, a part of any organized group effort. Mr. Sharpe, according to Lorene Harrison had been involved in the professional theatre prior to coming to Alaska. ${ }^{1}$ Not many plays were performed during the war except as part of music programs or Bonanza Days Celebrations. This mid-winter celebration offered melodrama rather than serious theatre. ${ }^{2}$

Interview (tape) with Lorene Harrison, Mrs. Harrison's home, Anchorage, Alaska. 18 July 1977.

2 Since the late 1930's Anchorage has celebrated a midwinter event called the Fur Rendezvous. This consisted, before the war, of sports events such as the World Champion Dog races and fur auctions. During the war, the event was suspended largely due to the evacuation. In its place, the three day celebration known as Bonanza Days brought back the 
Community theatre began in Anchorage at the end of the Second World War in much the same way as it has in innumerable cities and towns throughout the lower 48. A group of interested people with a common need to perform began to meet. During the latter part of 1945 and through February and March of 1946, the group met at the U.S.O. in the old log building at what was then the edge of town to discuss the possibility of forming a "dramatics" group. 3 Marilyn Wissler, active in the U.S.O., asked Lloyd Cleaves, also of the U.S.O., if the drama group forming could produce a full length play for public performance. Mr. Cleaves then proceeded to gather together a host of theatre enthusiasts interested in acting, make-up, or play production for the purose of starting a theatre group in the City of Anchorage. 4 It would seem that the initial intent was to present a full length play as part of the program and to have this first project completely sponsored by the U.S.O. The sponsorship by the U.S.O. would minimize the financial risk while giving an occasion to determine whether the group should go forward on its own initiative and under its own management.

By February 1946, the minutes of the meetings being

atmosphere of the Gold Rush Days with dance hall events and melodramas. After the war, the Bonanza Days eventually merged with the reinstituted Fur Rendezvous. May 1947 .

3 The Forty Ninth Star, vol 30, No. 39, weekly. 18

4 Ibid. 
held by the Anchorage Little Theatre Group reflect a definite plan to produce Ladies In Retirement by Edward Percy and Reginald Denham for an April 25th opening. Army Sergeant Bruce Marcus was selected as the director of this effort. Marcus, prior to his tour in the Army, acted professionally in New York but had no previous experience as a director. After rehearsals Marcus would sometimes go over the project with others who like himself had theatre experience. These included Charlton Heston, who worked at the Armed Forces Radio Station (AFRS) and had already begun his film career in 1942 and Frank Brink who was Program Director at radio station KFQD. Brink had been involved in theatre in New York and was to be a significant influence in Anchorage performing arts. Heston and Brink would visit with Bruce Marcus and discuss Marcus' project of starting a new theatre group. 5 Sometime during the early part of the rehearsal schedule for Ladies In Retirement Marcus lost the actor, Glen Dean Burgess, who was to play the part of Albert, a major role in the play. By the weekend of the 19th of April Marcus had not replaced the actor and had been going through it himself in rehearsal. It was quite clear that the production was in trouble. Marcus appealed to both Heston and to Brink to fill in. Heston declined, possibly because of the short time left before the planned opening on the 25th. According to. Frank

5 Interview (tape) with Frank 0. Brink, Shreveport Little Theatre, Shreveport, La., 20 November 1978. 
Brink, Heston's work schedule on the Army Post also may have prevented him from participating in the play. Marcus insisted that the play not be delayed nor rescheduled since the publicity had been released to the newspapers and the radio stations. Further, Marcus believed that he could not hold the cast and the crew nor get them back if the delay was very long. Then, too, this was Anchorage's first attempt at producing a full length play for public presentation. 6 When Brink finally viewed the troubled rehearsals, he knew that changes would need to be made if the show was to be saved. Since Marcus knew the role of Albert in the play by having rehearsed it himself, Brink convinced him to play the role of Albert. Marcus accepted Frank Brink as the show's new director. Brink further convinced the cast and the crew to take leave from their jobs in order to rehearse during the day as well as in the evening. Ladies In Retirement opened as scheduled and played to a very appreciative audience. Four performances were offered between April 25 th and the 28 th, free of charge, to capacity crowds at the U.S.0.7 The Anchorage Iittle Theatre Group at this time was represented by Mr. Archie I. Brown as Manager and Marian Knudsen as the Secretary-Treasurer. 8

6Ibid., Brink.

7 Anchorage (Alaska) Daily Times, 29 April 1946.

${ }^{8}$ Scrapbook, "Anchorage Iittle Theatre", Vol I, 1946-1947. 
After Ladies In Retirement, the new theatre group felt confident it could continue without the support of the U.S.O., although it did not incorporate as a non-profit organization with the Territory of Alaska until J. Earl Cooper, an attorney in town, became an active member. Mr. Cooper had been impressed with the production of Ladies In Retirement and with the group's new artistic leader, Frank Brink. Earl Cooper assisted in giving the group its formal structure, and by the A.L.T.'s second show, Our Town, presented in June of 1946, the group had a Board of Officers that consisted of:

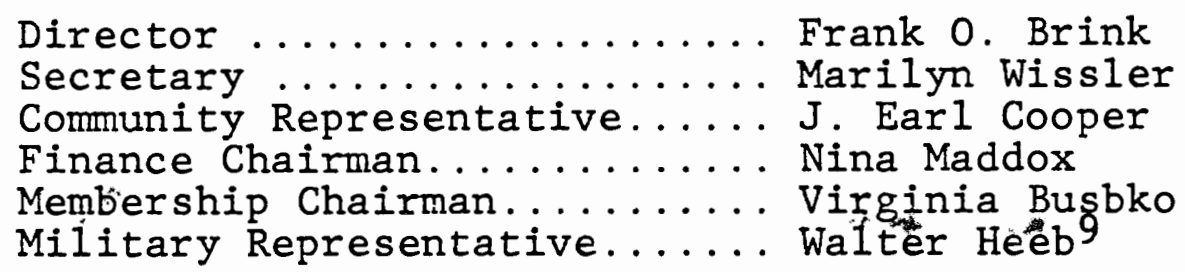

The A.L.T. was comprised of 17 members during Ladies In Retirement. The Our Town playbill reflects a charter membership of 58.10 The financing for Our Town was achieved by appealing for donations by the business community in Anchorage and by charging members of A.L.T. a $\$ 3.00$ membership fee. This production was also the first A.L.T. show to charge for tickets. At a ticket price of $\$ 1.20$ (including Federal and Territorial taxes), Our Town brought in $\$ 1,294.65$

9Playbil1, the Anchorage Little Theatre's production of Our Town, Anchorage, Alaska. 22 June 1946.

10 Ibid., Many of the records show Our Town as A.L.T.'s first production, not counting the U.S.O. sponsored Ladies In Retirement as being the first show. 
from three performances presented at the 500 seat high school auditorium on June 22, 23, and 24, 1946. Anchorage Little Theatre's audit of May 1948 showed a profit for the show of nearly $\$ 490.00 .11$

Anchorage Little Theatre applied for papers of incorporation in September of 1946, just before presenting a third and somewhat troubled production. ${ }^{12}$ Arsenic and 01d Lace by Joseph Kesselring was scheduled for presentation in August of 1946 but two events delayed the opening. A rotation of a particularly large number of servicemen to other duty stations decimated the cast and crew of the show. In addition, an outbreak of diphtheria in late August resulted in a general quarantine of the City. After the quarantine, the Anchorage Little Theatre recast and proceeded with the show, giving four performances of Arsenic and Old Lace between October 9 th and the 12th, at the high school auditorium. ${ }^{13}$ The show made about $\$ 1,000.00$ net profit and was reviewed by the Anchorage Times as presenting, ". . .performances (that were). . rough in spots, but nevertheless provided good entertainment. 14

$11_{\text {First Audit }}$ of the Anchorage Little Theatre Inc., 27 May 1948.

12 Anchorage (Alaska) Daily Times, 14 September 1946.

13 Arsenic and 01d Lace was scheduled for three performances but the group gave an additional benefit show october 12th for the Alaska Crippled Children's Association.

${ }^{14}$ Anchorage (Alaska) Daily Times, 12 October 1946. 
When Frank 0. Brink came to the aid of Ladies In

Retirement, he embarked on a journey that would make him one of the major contributors to the cultural growth of Anchorage. Before the war, Frank Brink graduated from Maryville College in Tennessee with a B.A. in Speech and Drama. He worked in the theatre in New York and, before enlisting in the Navy, began| a fellowship in the Drama Department at the University of North Carolina. Much of his Navy duty during the war was spent in the south Pacific, but in 1944, he was returned to the State of Washington for additional training in antisubmarine warfare. It was prior to his release from the Navy in september 1945, that he answered an ad in a seattle newspaper that resulted in his becoming Program Director and announcer for radio station KFQD in Anchorage, "I always had a desire. . . to experience the adventure of Alaska. After the experience in the south Pacific, the thought of going back to school seemed so tame. . . I thought I'd try Alaska for a year or two."15 In early November of 1945 Frank and his wife Jo moved to Anchorage.

Because of personal differences with KFQD's station manager, Bill Wagner, Brink resigned his job in 1946 and homsteaded for a while. Between his employment at KFQD and his later work with a new radio station, KENI, in 1948, Brink supported his family by working at several odd jobs,

15 Interview (tape) with Frank 0 . Brink, Shreveport Little Theatre, Shreveport, La., 20 November 1978. 
stocking groceries, working with the Department of the Interior, washing railroad cars and operating a small ice cream business. The ice cream venture was terminated by a Seattle dock strike in early 1948. ${ }^{16}$ During this time, he directed all the Anchorage Little Theatre shows from April 1946 to the second production of Dickens' A Christmas Carol in December of 1947. He also assumed artistic leadership of the successful new theatre group.

Inevitably the question of time and energy committed by Brink had to be faced. It was an on-going problem which plagued him throughout his thirty years in Alaska arts activity. During the forties and long after there was no living wage to be made in the community theatre. Even in later years when Brink was teaching theatre he experienced the problem of having enough energy left over from his professional responsibilities to give to the community theatre as a volunteer. When Brink went to work in early 1948 for the new radio station KENI he could no longer divide his time as freely with the theatre as he could when working at odd jobs. His professional duties which consisted of writing and producing radio scripts as well as the required travel in the bush fully consumed his time and energy. Brink had to choose between radio and the community theatre. If he was to continue with the Iittle Theatre, he would have to be paid.

${ }^{16}$ Ibid., Brink. 
As early as March and April of 1947, several meetings revealed that the A.L.T. was wrestling with the question of how to pay a full time managing director for the group.

While the group was doing well at the box office, the financial records did not show the kind of a surplus necessary to commit the group to a full time salaried position. The Anchorage Little Theatre at one time wrote to Theatre Arts magazine for advice on solutions to this problem but to no avail. ${ }^{17}$ This was a time before such programs as the National Endowment for the Arts and other funding programs. While there were some Foundations in existence during the forties to help the arts through private efforts, the Alaskan community artists were not aware of them nox how to acquire such funding aid. A.L.T. member Shirlie see said that the group elected to put any surplus monies into a building fund. ${ }^{18}$ Thus, the matter of hiring a permanent managing director was shelved and Frank Brink limited his involvement with the Anchorage Little Theatre from 1948 to 1952.

The Anchorage Little Theatre adopted a structure in 1948 that provided a "Production Panel" appointed by the theatre's Board of Directors. There was a Concert Department and a Symphony Department as well as Ways and Means, ByLaws, Membership, and Publicity committees. The Panel was

\section{${ }^{17}$ Anchorage (Alaska) Daily Times, 25 March 1947. \\ 18 Interview (tape) with Shirlie See, Mrs. See's} home, Kasilof, Alaska, 3 February 1979. 
an intricate and somewhat cumbersome structure for such a young group but, nevertheless, it was an attempt to grow beyond the initial impetus of Frank Brink's leadership. The concept implies an artistic movement such as the Little Theatre could better survive by committee after its establishment by a creative individual.

In February 1948, the Anchorage Little Theatre began a tradition of producing melodramas and olio variety acts for the annual Fur Rendezvous Celebration, and was now using several different directors for productions. Arthur B. "Tobie" See and his wife, Shirlie, began to direct for the group, as did Hal Bochoven, Lloyd Cleaves, Lorene Harrison, Ellen Maxon, and many of the other members. ${ }^{19}$ The Sees provided the artistic leadership after Brink became less active with the grcup. "Toby" and Shirlie See came to Anchorage from Bethel, Alaska, where "Toby" had worked with the Corps of Engineers, having been transferred to Anchorage in the early forties. The sees joined A.I.T. just before its Our Town production. 20

In addition to producing plays, the Anchorage little Theatre helped established the Symphony, the Concert Association, and the Community Chorus. In the summer of 1946, Edrard DePaul came to A.I.T. and found a home for the

${ }^{19}$ Flaybill, the Anchorage Little Theatre's production of "Bonanza Days", February 26, and 27, 1948.

20 Interview (tape) with Shirlie See, Mrs. See's home, Kasilof, Alaska, 3 February 1979. 
development of a small symphony orchestra. Among the membership of the Iittle Theatre, there were about 13 instrumentalists who formed an orchestra known then as the Anchorage little Symphony. After conducting the new orchestra in the first A.I.T. production of Dickens' A Christmas Carol in 1946, DePaul left the Territory. Sergeant Robert Wright replaced him in January of 1947 but never directed a concert with the group. By the time the Anchorage Little Symphony played its first concert in March of 1947, the group was under the baton of Charles Eroh. The Symphony eventually broke off from the sponsorship of A.I.T. and went on its own in March of 1948, the leadership of Peter Britch.

Foday's Anchorage Concert Association which sponsors performing artists from all over the world also had its beginnings in the Anchorage Little Theatre through the efforts of Lorene Harrison and Anne Dimond. In 1947 the A.L.T. brought pianist Grant Johannesen to Alaska to perform. Out of this program grew the practice of bringing in artists to play in Anchorage and then having other communities such as Fairbanks and Juneau host the same artist, thus sharing the cost and giving the artist a larger audience for which to perform. The tours became known as the Alaska Music Trails and was largely the idea of Max Shapiro, a pianist who appeared in Anchorage in $1948 .^{21}$

21 Interview (unrecorded) with $\mathrm{Dr}$. Robert Wilkins, Executive Director of the Anchorage Concert Association, 21 March 1979. 
Lorene Harrison was instrumental in establishing the Anchorage Community Chorus. Mrs. Harrison had directed the Women's and the Men's Glee Club in the 1930's, the Presbyterian choir, as well as the musical requirements of several A.I.T. plays. In the winter of 1946-47, Lloyd Cleaves, Lorene Harrison, and Frank Brink began to investigate the feasibility of presenting Handel's Messiah, and thus the Anchorage Little Theatre became the producer of the first major chorus production in Alaska. To implement the plan, Mrs. Harrison organized the United Choir of All Faiths, as it was known, by inviting several of the church choirs in town to participate. "We had about a hundred voices. . .and it was pretty darn good."22 The Anchorage Times of April 2nd, 1947 acclaimed the production as "impressive". 23 During this first presentation of the Messiah the members of the choir were already deciding to form a municipal chorus separate from their respective church choirs. ${ }^{24}$ The Commity Chorus eventually went on its own by separating from the A.I.T. in 1950 .

Frank Brink, who helped to guide A.L.T.'s initial development, directed nothing on stage between 1948 and 1951. He did, however, assist A.I.I. backstage and was counsel to

22 Interview (tape) with Frank 0. Brink, Mr. Brink's home, Anchorage, Alaska, 15 March 1973.

23Anchorage (Alaska) Daily Times, 2 April 1947.

24Anchorage (Alaska) Daily Times, 1 April 1947. 
the group. Frank's own creativity during this period was invested in his work at radio station KENI where he and other broadcasters such as the late Ed Stevens and poet Ruben Gaines produced radio drama. In casting some of KENI's radio dramas Brink drew on members of the Anchorage Iittle Theatre. After being recalled into the Navy during the Korean Conflict, Brink served as Information Officer between 1951 and 1953 on Kodiak Island, three hundred miles south of Anchorage. 25

The supply of performing facilities in Anchorage was as far behind the demand in the forties as it is today. In 1928, the high school music department had to present "Miss Cherrybloosom" in the old Empress movie theatre. In the late $1930^{\prime}$ 's, the high school auditorium, which had a seating capacity of 500, was built adjacent to the existing high school in downtown Anchorage at 6 th Avenue and $G$ Street. This facility accommodated both the school's needs and the growing demands of the community, especially after the development of the A.I.T. programs in 1946. The American Legion Log Building which accommodated nearly 200 seats was the facility in which Ladies In Retirement was performed. The demand on this facility was great and the stage was small, limiting the scope of many productions and concerts. The Ark, another facility, was built in 1923 to house the

25 Ibid., Brink. 
making of a major silent film entitled, "The Cheechako". 26 To begin with, this large log building had been used for indoor sports and carnivals, and, prior to building the high school auditorium, it served the assembly needs of the school. 27 There was no permanent stage and the large facility did not easily adapt to the needs of a theatre program.

Rental rates and policy varied through the years in all the facilities. Generally, cost for use was levied either by a percentage of the event's gross or a flat rate. A group's particular affiliation with the school or the City many times affected, in a favorable way, that group's ability to gain a priority in being granted use of a facility. Such is the case to this day in Anchorage. Anong the first affiliate arrangements with the City was A.I.T.'s traditional melodrama during the Fur Rendezvous which assured A.I.T. a place to play during the City's celebration. But a price was exacted for being part of the Fur Rendezvous. Fifty

26 The term, "Cheechako", as legend would have it, means a newcomer to Alaska. When early miners from Chicago came, the natives couldn't pronounce Chicago and thought al1 Whites were "Cheechakos". After the first year, a "Cheechako" becomes a "Sourdough".

27 The Ark was built through the efforts of Alaskan Industrialist, Cap Lathrop and was originally named the 'Movie Studio'. When the film, "Cheechako" was ready for marketing, the advent of sound destroyed the potential for the film. The City took over the log building and renamed it the 'Community Fall'. Eventually the facility came under the stewardship of the Anchorage Recreation Klub, thus the name of the building from the acronym A.R.K. According to Anchorage Times publisher, Robert B. Atwood, the Ark was torn down in 1948 because, "... it was utterly worn out". 
percent of the participating group's income during the celebration was turned over to the Rendezvous.

By the end of 1947, the Anchorage Little Theatre had a firmly established community theatre operating. From then until 1953, the A.L.T. was the only theatre group in the Anchorage area. ${ }^{28}$ The Anchorage High School put on productions about twice a year and in 1946, about the time A.I.T. was forming, the Anchorage High School was admitted to the National Thespian Society as Chapter $700 .{ }^{29}$ Within its first two years, the Anchorage Little Theatre had established an umbrella for an orchestra, a concert series, and the beginnings of a community chorus. By 1950 the music programs of the community theatre had gone their own way largely in view of the fact that the Little Theatre simply could not manage it.

There is an argument that if the Anchorage Iittle Theatre had paid a managing director the group could have held on to both the theatre and the music programs, but it seems unlikely that the orchestra or the concert or chorus would have remained rather than working towards their own goals. Its been the history of Anchorage's performing groups that one group forms by spinning off from another

28 On the Fort Richardson Army Post, the Post Players would, on occasion, produce a play or variety show for the servicemen and their dependents.

${ }^{29}$ Anchorage (Alaska) Daily Times, 15 March 1946. 
more established group. The Anchorage Little Theatre, in any case, is owed a great debt for providing the foundation on which the performing arts were launched so well in post-war Anchorage. 


\section{THEATRE GROUPS BLOSSOM}

The decade of the fifties was a very fruitful time for theatre development in Anchorage. The performing arts grew as quickly as the community's population. Between 1950 and 1960 the Anchorage area grew from about 30,000 people to over 82,700 , an increase of over $158 \%{ }^{1}$ In this decade the Federal Government remained the City's chief economic support. In 1951 Elmendorf Air Force Base was established immediately north of the City, absorbing that part of Fort Richardson Army Post known as Elmendorf Field. With this increase in population came the increase in performing arts activity. Five theatre groups in addition to the Anchorage Little Theatre evolved during the decade. Four of the six would still be producing in 1960. The theatre activity during this period reaped the support and the participation of the community. Other leisure time activities such as clubs, sports and other spectator events were not yet developed enough to attract audiences away from the theatre. It was during the fifties that the musical entered the repertoire of the Anchorage theatre.

IDecennial Census of the United States, April Ist of each year. 
In 1952, Frank Brink staged the new musical South Pacific for the Anchorage audience. The show had been presented the year before for the Armed Services. Brink had been involved as co-director when the show was produced by the military. ${ }^{2}$ Rodgers and Fammerstein insisted that an existing organization be the producing authority for the 1952 production. Brink was still in the Navy and not yet in a circumstance to launch another theatre group. Therefore Brink had to convince the only theatre group in town, Anchorage Little Theatre, to be the show's sponsor. According to former A.L.T. member, Shirlie See, South Pacific was not financially profitable for the theatre group. Part of the conditions of gaining the rights to the show was that no organization make any profit from the presentation in Anchorage. Therefore, the show was offered free to the military and at a minimum cost to the civilian audience. ${ }^{3}$

The idea for a new and somewhat diversified theatre group began to germinate during the 1952 South Pacific production. With the help of Mary Hale, music director for the South Pacific production and of the Anchorage Community Chorus, Frank Brink and a few community leaders, such as

2 The 1951 production of South Pacific had been produced by the Alaskan Air Command through a special license from Rodgers and Hammerstein. The show was toured throughout the Command; Brink had co-directed with Rodgers and hammerstein's Chicago State Manager, Ross Bowman.

3 Interview (tape) with Shirlie See, Mrs. See's home, Kasilof, Alaska, 3 February 1979. 
Judge J.L. MacCarey and Lorene Harrison, laid plans for a project known as the Alaska Community Theatre. More than a play production group, the Alaska Community Theatre was to be the parent to other art groups throughout the Territory much like the Anchorage Little Theatre had been to the fledgling music groups in Anchorage during the previous decade. The Alaska Community Theatre idea included a proposed school of theatre. Brink was to be the Managing Director of the Theatre group and the head of the Drama School. 4 Mary Hale was to provide the music leadership for the project. She was also the secretary for the newly organized group. A.C.T.'s goal was to provide a Territorial center for cultural development in Alaska. The A.C.T. project would also provide a career position for Brink and possibly a few others in the Anchorage arts. The idea of a paid theatre job for Frank Brink had not worked out in 1947 when the Anchorage Little Theatre decided in favor of saving its money for a building. 5

During 1953, there was a great effort by Brink, Mrs. Hale, and others to find funding for the Alaska Community Theatre project. Tuition and production revenue would not be able to support such a venture. In March of 1953, after he was released from the Navy, Frank Brink went into

4 Interview (tape) with Mary Hale at the Anchorage Community College campus, Anchorage, Alaska. 18 July 1977.

5 Ibid. 
business making radio commercials and acting as a consultant for the first Alaskan television station, KTVA, which went on the air December 18, 1953. While the search for funding went on and Brink worked at odd jobs, the Alaska Community Theatre presented several productions to demonstrate that it was an operating theatre organization. Brink directed Mary Chases' Harvey and a two part musical presentation consisting of Kurt Weill's Down in the Valley and Brink's own musical play, Ballad of No Name Town. During this same year, the Alaska Community Theatre created the Anchorage Film Society with Mrs. Betty Cuddy as its first director. The Film Society showed a film each month to its membership.

The Alaska Community Theatre project failed to get its funding. In fact, the services A.C.T. proposed to offer were implied by the Anchorage Community College when it was established by the Legislature in 1953 and opened to students in January 1954. Under the Act, the Anchorage Independent School System established A.C.C. and with each passing year, the University of Alaska, Fairbanks, would take over onetenth of the new school's support. ${ }^{6}$ The creation of the Community College spelled the end of the Alaska Community Theatre project because the new Community College was assured of public funding.

${ }^{6}$ While the Community Colleges of Alaska have their own system and are fighting for an autonomy of their own, they are still under the authority of the University of Alaska, Fairbanks. 
There were plans to build a 2,000 seat auditorium, adjacent to the new high school on Romig Hill, on Anchorage's southwest side. Thus through the high school, the new College would have a publicly funded facility to perform in. Mary Hale saw this as soon as the new College became a reality. ${ }^{7}$ Further, the Community Chorus and the Anchorage Symphony joined the new college as affiliates. Brink resisted and viewed the rush to the new College as a desertion from the Alaska Community Theatre idea. Frank must have viewed the Community College as an encroachment on the autonomy of the theatre arts program of A.C.T. Mary Hale saw no such threat to the Chorus from the affiliation with the new school. Indeed, Mary Hale suggested, according to Shirlie See, that the Anchorage Little Theatre consider such an affiliation with the new College. A.I.T., however, declined for the College was under the authority of the Anchorage Independent School District at that time and A.L.T. feared, much as did Brink, an unwelcome influence on the theatre's program. Further, the Anchorage Little Theatre was still doing well at the box-office and didn't yet need help. 8

Brink's disappointment over the dissolving of A.C.T. was appeased when the first director of the new Community

7 Interview (tape) with Mary Hale at the Anchorage Community College campus, Anchorage, Alaska. $18 \mathrm{July} 1977$.

8 Interview (tape) with Mary Hale at the Anchorage Community College campus, Anchorage, Alaska. 18 July 1977. 
College, Dr. Leroy Good, offered Brink a job as a faculty member and the opportunity to use the College as the home of a new community theatre group. The Anchorage Community

College Theatre Workshop became Anchorage's third community theatre group. Brink and Dr. Good agreed that as long as the college invested no money directly in the Theatre Workshop's productions, the group could enjoy most of the advantages of affiliation but remain an independent entity. To keep its identity clear, the Theatre Workshop incorporated as a non-profit, educational organization in 1956. Brink wished to forestall any influence the school might impose on the affiliates. While the agreement between $\mathrm{Dr}$. Good and Frank Brink was verbal, a 1958 memo by the Collegie's second director, Mr. Mel Huden, concluded that the Anchorage Community College Theatre Workshop was viewed as an official "instrumentality" of the College and yet independent of the College as a civic organization. ${ }^{9}$

The Theatre Workshop, under Brink's direction, enjoyed a period of phenomenal success as a community theatre

9 Memo from Mr. Mel Huden, Director of the Anchorage Community College, to the Board of Trustees of the Anchorage Independent School District, 15 Mary 1958:

"Theatre Workshop: This is not an "affiliate organization" at all. Rather it is an official instrumentality of the Community College under the head of the Drama Department and Director of the College. Officials are not elected, but appointed annually by the Director and all actions, financial and othervise, are subject to veto by the Director. There is extensive volunteer, lay community participation, in the best tradition of community college philosophy." 
between the years 1954 and 1960. Part of this success was due to a man named Donald M. Gretzer, an administrator with the Civil Aeronautics Administration in Alaska. Beginning in 1954, Don spent his leisure time working with the Theatre Workshop. He did much of the tape recording and other sound work for the production and for the Community Chorus as well. Gretzer and Brink formed a kind of partnership in which Brink acted as the artistic leader of the Workshop and Gretzer the administrator (President) and business manager of the organization. The Theater Workshop had among its membership a very talented staff of both volunteers and, for a short while, a few paid workers. The Anchorage Community College's Art Department had an instructor named A.E. "Betty" Park. In Betty Park Brink found a scenic designer whose special talent was painting perspective scenery. The joint efforts of Betty Park and the Theatre Workshop's Technical Director, John F. Villesvik were extremely successful from 1957 to 1970, when Betty stopped designing sets. At the height of the group's success in 1958, John Viliesvik was at full salary with the Workshop and Betty was paid for each show she designed. Promotional Director, Ms. Jackie Sewell was also paid as a part time staff member. Stipends also were occasionally paid to others but, for the most part, the production people and the actors were volunteers. Brink was paid only when directing such sumer shows as the King and I (1957) and Brigadoon (1959). Eecause of his position as head of the 
Speech and Drama Department of the Community College, Brink was never paid for shows produced during the academic year, since he was already on salary from the College.

Once a part of the new College, Brink realized that the University of Alaska would eventually provide the Territorial wide theatre education which had been the goal of the Alaska Community Theatre. Frank knew that with the growth of the College and, indeed, of the community of Anchorage, he would need to upgrade his own credentials beyond his B.A. degree. Through the Spring and Sumer of 1954 and 1955, Brink went to Montana State University to earn his M.A. in Speech and Drama. For his thesis project he. wrote a five act pageant on the life of Alexander Baranof, an 18th century Governor of the Russian territories in America. The pageant, "Cry of the Wild Ram" was produced in Anchorage in July of 1960 and again in 1961. Since 1967, the City of Kodiak has produced the work annually at a natural amphitheatre near Monashka Bay on Kodiak Island.

For the years 1954 and 1955, the Theatre Workshop was prevented from mounting a major production for want of a place to perform in the Anchorage area. The old high school downtown had burned down in 1952 and neither the new 2,000 seat Romig Hill Auditorium next to the new high school nor the proposed 650 seat municipal auditorium downtown were ready. Other facilities such as the First Presbyterian Church basement and the Legion Log Cabin were under heavy demand by organizations outside the College. The Theatre 
Workshop did work and perform a limited theatre program in a double classroom at the new Anchorage High School. 10

In anticipation of the opening of the new Romig Hill Auditorium, Brink tried to arrange for a professional actor to come to Anchorage and perform in a play with the community players for the opening of the facility, but was not successful. In January 1956, the Theatre Workshop presented its first production, Sydney Kingley's Detective Story at the new auditorium, with Frank Brink playing the role of McLeod.

In 1955, a local radio announcer, Jack Wandell, formed Anchorage's fourth community theatre group, the Anchorage Drama Lab. Even though still a member of the Theatre Workshop at the time, Wandell wanted more freedom to practice a particular 'school' of acting, this is "the method" as taught at the Actors' Studio in New York City. In the summer of 1955, Wandell staged Tennessee Williams' A Streetcar Named Desire. Shortly after the January 1956 production of Detective Story, which Wandell directed, Jack broke with the Theatre Workshop in view of his inability to work with Frank Brink. 11 The Anchorage Drama Lab centered around

10For six years, the Theatre Workshop met every Tuesday night and worked on scenes, one-acts, and various other theatre projects. Occasionally, the members, "the Tuesday night group" would stage an evening of one-acts with student directors for an invited audience.

11 Interview (tape) with Frank 0. Brink, Mr. Brink's home, Anchorage, Alaska. 15 riarch 1973. 
Wandell and his friends who financed the group out of their own pockets.

The essentials of any functioning theatre program are the availability of a facility in which to perform, an audience to support the efforts, and the leadership or Board authority to develop and continue programs of performance. The attempts of the major military installations near Anchorage to foster theatre programs demonstrates an example of why theatre projects may succeed or fail. During the late summer of 1955, an enterprising airman, Mike Campbell, on Elmendorf Air Force Base initiated the fifth nonprofessional theatre group in the Anchorage area. The new group was known as the Elmendorf Theatre Guild. The, Guild was under the authority of the Central Base Fund. This, of course, meant that the Elmendorf Theatre Guild had to turn their net revenue over to the Base Fund. It also meant that the group would be bailed out should the Guild lose money on a show.

The success of the Elmendorf Theatre Guild was due largely to the fact that it had a home in the form of an old wood-frame church converted to a theatre facility. It was named the McKinley Playhouse and the group both rehearsed and performed in the building without having to share its use with other Base functions. The close proximity of Elmendorf Air Force Base to Anchorage aided the Guild in drawing the talent and especially the audience support from the Anchorage community to supplement the support from Base residents. Neither Elmendorf nor its reighbor, Fort 
Richardson Army Post, have been able to support a theatre program without relying on the civilian population. Shortly after Airman Campbell started the theatre group on Elmendorf, Lieutenant Colonel Maurice Costello had assumed a leadership role in the group. Both Colonel Costello and his wife, Dorothy, had enjoyed working in amateur theatre throughout his military career. Colonel Costello was a very influential liaison between the theatre group and the Air Force authorities. As long as Maurice Costello was in the Guild, the group had the use of the building and was able to present a consistent theatre program for several years. The Air Force had wanted to scrap the old building but Costello was able to avert this in behalf of the Guild until he was finally rotated out of Alaska in late 1963. Shortly afterwards, the Air Force sold the building for salvage. Without a place to perform, effective leadership, or support from the Base, there was no hope for the Elmendorf Theatre Guild to continue a play production program.

In contrast, the Fort Richardson Army Post rarely experienced success at having continuous theatre programming since Fort Richardson did not offer the support that the Elmendorf Theatre Guild received from the Air Force. There were various attempts during the late 1940's and the 1950's and as recently as 1976 , to sustain a continuous program of play production on the Post. These efforts failed miserably without a building in which to rehearse and to perform. On occasion facilities were made available for specific theatre 
production, to this extent this availability could not be projected throughout an entire season on Post. As with the Elmendorf Theatre Guild, any theatre effort on the Post needed the support of the Anchorage civilian audience to supplement the interest of those on the military installation. Most military residents were single enlisted personnel who were more inclined to spend their leisure time away from rather than on the military reservation. The need to attract a civilian audience for any theatre effort on Post was complicated by the ten miles between the Post's main gate and the community of Anchorage. While this was no great distance, there was plenty to do and to see in town throughout the fifties and such a trip could be an imposition. In addition, the various attempts to develop a theatre program on Post lacked any sustained leadership to carry such a movement on. Since a group theatre effort would be, like the Theatre Guild on Elmendorf, at the convenience of the Army, a Board of Directors would not likely have the authority necessary for any Fort Richardson theatre program to have endured. Community actor Robert Cremonini tried to get a theatre group started during the post Players' 1956 production of Alan Jay Lerner's Brigadoon. 12 Cremonini, though, didn't have the inclination to stay with the effort because of his own

12 Throughout the forties and the fifties the theatre efforts on Fort Richardson have been at one time or another called "The Post Players" or the "Fort Rich Players" and in the case of 1959, the "Fort Richardson Theatre Guild". 
commitment to the Anchorage Drama Lab. After his discharge from the Army, Cremonini's influence on Post ended. Walt Downs, though a civilian, tried along with several of his friends to copy the Elmendorf Theatre Guild idea by creating the Fort Richardson Theatre Guild in 1959. It did not last beyond its first production, Don Juan in Hell, the fourth Act of Bernard Shaw's Man an Superman, which can be played as a production in itself. 13 Neither Mr. Downs nor his friends stayed with the effort.

In 1976 facilities, support from the Army and a leader made it possible to begin yet another theatre program on the Army Post. A grant from the Department of the Army was made available to provide a recreational program in theatre for the Post. One of the movie theatres was altered into a theatre for play production. Mr. Frank Johns began producing and directing plays on the Post with varying degrees of success. Despite the facility, the grants, and Mr. John's leadership, the Fort Richardson theatre effort is still not able to draw sufficiently upon the Anchorage community. Mr. Johns left the state in early 1979 and the theatre effort on the Post has become, again, intermittent.

The Anchorage Little Theatre performed throughout the 1950 's but never with the kind of success it had enjoyed during the late 1940's. The A.I.T. was no longer the only

13 Interview (tape) with Walter Downs, Mr. Downs' office Anchorage, Alaska. 6 April 1979. 
performing arts organization in the Anchorage area. The group now had to compete with the other theatre and music groups for the leisure time audiences. It seemed to be the role of the Anchorage Little Theatre to begin it all, and then after the 1952 production of South Pacific, the group's development appeared to have leveled off. To be sure, there were successful shows. Until 1958 the Anchorage Little Theatre continued to have the Fur Rendezvous sponsorship for staging the annual melodrama. The 1953 production of Robinson Jeffer's Medea as directed by Ellen Maxon was very well received by the Anchorage reviewers. ${ }^{14}$ Mrs. Maxon staged the piece as a formal platform reading and thus avoided some production expenses. Another example of saving the cost of producing a show was the November 1953 production of Ladies of the Jury by Fred Ballard which was directed in the round by Shirlie See. The production was staged at the Veterans of Foreign Wars Hall. According to the Anchorage Times review, the production could only seat 150 people at each of the three performances. ${ }^{15}$ But after November 1957 , when A.I.T. presented A Witness for the Prosecution by Agatha Christie, the membership displayed a disinterest in the group's program. Shirlie See maintains that when less than nine A.I.I. Board members attended the meetings, the

$$
\begin{aligned}
& { }^{14} \text { Anchorage (Alaska) Daily News, } 11 \text { May } 1953 . \\
& { }^{15} \text { Anchorage (Alaska) Daily Times, } 20 \text { November } 1953 .
\end{aligned}
$$


group was not legally functioning according to its incorporated By-laws. She thought that it would have been better to dissolve the group while it was still solvent instead of ending ir debt as it did in 1961. 16 Nevertheless, the Anchorage Little Theatre continued, though intermittently, to produce nlays. In April of 1959, Ms. Jo Downs staged Guvs and Dolls at the Sydney Laurence Auditorium in downtown Anchorage. Jo and her husband, walt, had acted and otherwise participated with all the theatre groups in the Anchorage area. Between 1959 and the apparent end of the Anchorage Little Theatre group in 1961, A.L.T. only functioned when Ms. Downs wanted to do a project. Like Jack Wandell of Drama Lab, Jo used the group's name as a sponsorship for theatre pieces she wanted to produce. The last show under the name of the Anchorage Little Theatre was The Man With the Golden Arm which was directed by Walt Downs in October of 1961 and performed at the Sydney Laurence Auditorium. In 1964 upon return after a two vear absence from Anchorage, Jo and Walt Downs decided not to continue with the name of Anchorage Little Theatre. They changed the name of the group to the Carnival Civic Theatre and presented musicals, for the most part. The name change was prompted by the fact that the A.I.T. name had suffered through losses on shows and it was known that the group had to sell its land in 1960 to pay its

16 Interview (tape) with Shirlie See, Mrs. See's home, Kasilof, Alaska. 3 February 1979. 
debts. Jo thought she would have a better chance for success with a new name for the group. 17

One of the most important aspects of a community arts program is its funding. Prior to the late sixties when grantsin-aid became a major source of funding, the manner in which a performing group in Anchorage financed its projects had changed little. The beginning of community theatre in Anchorage, Ladies In Retirement, was paid for by the U.S.O. and presented at no cost to its audience. For A.I.T.'s 1946 production of Our Town, the producers charged the necessary purchases and solicited donations. Mainly, the practice of charging production costs and then paying back the charged accounts around town out of the box office was the procedure of funding comunity performing arts to defray production costs.

The idea of applying for grants was quite foreign to most of the arts leaders prior to 1960. During the forties and the fifties, the concept of pay-as-you-go was the finance concept in the Anchorage performing arts groups. It was viewed as essential that a show either broke even or showed a profit. Those producing shows that did lose at the box office, usually found themselves taking morey from their own pockets to meet the deficit. The Theatre Workshop brought in Boris Karloff (1957), Will Rogers, Jr. (1958), Jan Peerce

17 Interview (tape) with Walter Downs, Mr. Downs' office, Anchorage, Alaska. 6 April 1979. 
(1959), and Theresa Wright (1960) and proved able to bring in their expenses through the box office. The contracting of Boris Karloff was possible through loans taken out by individuals to establish the necessary guarantees. The Alaska Festival of Music, created largely through the efforts of Mary fale in 1955, brought in international performing artists for little or no fee except subsistence. The costs not covered by the box office were provided through donations from the business community. Towards 1960, the expense of providing the Alaska Festival of Music was getting higher than even the generous donations could support.

It was Mary Hale who acquired grants to support Arts in Alaska. Because of her concern over the need for subsidy Mrs. Hale's friend mountain climber Bradfort Washburn advised her to seek grants from various foundations. ${ }^{3}$ on her own resource, Mrs. Hale went to New York in 1960 and with the help of fund raising consultant Robert Conrad, Mrs. Hale learned the complicated procedures necessary to acquire subsidy for the arts. She gained grants for the Festival of Music between 1961 and 1966 and thereafter helped launch the State Council on the Arts. Alaska's participation in the National Endowment for the Arts frogram was set in motion. 19

13 Explorer Bradfort Washburn was the first man to successfully climb the 20,000 foot lit. McKinley. Many of his explorations were funded by various Foundations.

19 Interview (unrecorded) with Mary Hale at the Anchorage Community College campus, Anchorage, Alaska. 7 August 1979. 
of the four theatre groups that performed consistently throughout the fifties, the Theatre Workshop appears to have been the most successful owing, in part, to Brink's decision to bring professional actors to 'star' in local productions. Boris Karloff was brought to Anchorage in March of 1957 to play in a show with which he was closely identified, Joseph Kessering's Arsenic and 0ld Lace. ${ }^{20}$ As far back as his days with the Anchorage Little Theatre, Frank Brink had wanted to bring a professional actor to Anchorage. Finally in 1957, Brink brought the first of several professionals to perform with local casts. The Karloff appearance was immensely successful. Later, in 1960, Hedda Hopper quoted Karloff in her column in the I.A. Times, in which Karloff said, ". . . three years ago I played in (i.e. Arsenic and Old Lace) in Anchorage, Alaska, a place so remote that the people have to create their own entertainment. The local group rehearsed over two months in their school auditorium. . we did three performances which were a roaring success. I wouldn't exchange anything that's ever happened. for that experience." 21 The success of Mr. Karloff's appearance was not only measured in the box-office profit nor in the fact that

20 Arsenic and 01d Lace was previously produced by the Anchorage Little Theatre in October of 1946 . The production was directed by Frank Brink.

21Los Angeles (California) Times, Hedda Hopper's
column. 13 Septemter 1960 . 
Karloff donated must of his percentage of this profit of $\$ 7,631.24$, but in the fact that Boris Karloff became a reference and aid in convincing other talents to come to Anchorage. 22

The practice established by the Theatre Workshop of importing professional actors for Anchorage productions might be viewed as a key to the success of a community theatre program. This, however, does not hold true when compared to the experience of the Anchorage Drama Lab in 1960. The Theatre Workshop between 1954 and 1959 had a solid organization and most importantly, a business manager or administrator in the person of Donald Gretzer, President of the group. One of his chief responsibilities was to carefully organize the 'star's' entire stay in Anchorage including his financial guarantees, the itinerary while in town and the personal accomodations for the guest artist. This included sightseeing trips to show off Alaska to the guest performer. ${ }^{23}$

In contrast, the Anchorage Drama Lab did not experience the success of the Viorkshop when Jack wandell brought up James Whitmore and Arthur Franz to perform in two of the Drama Lab's productions in 1960. In February of 1960 Whitmore played the lead in the Drama Lab's production of The

22 Accounting Balance Sheet, Profit and Loss for the Theatre Workshop as prepared by Rettic and Scott and Co., C.P.A. dated June $30,1957$.

23 At his request, Will Rogers, Jr. (1958) was flown to visit the sight of his father's crash at Pt. Barrow, Alaska. 
Hairy Ape by Eugene O'Neil. The following June motion picture actor Arthur Franz came to Anchorage to appear in an original play by broadcaster and poet, Ruben Gaines, entitled "Adam's Harvest". It is safe to assume that Jack Wandell was imitating Brink and hoping for a similar success. In the case of the Drama Lab, bringing professionals to Anchorage did not help the production's financial success and certainly did not contribute to the continuance of the Drama Lab. Inlike the Theatre Workshop, the Drama Lab was poorly organized and had no responsible administrator other than its artistic leader, Jack Wandell. The Anchorage Drama Lab existed from 1955 to about the end of 1960. Wandell did not incorporate the drama group and was only interested in having a laboratory for his actors. Beyond this there was no structure in the group for sound business operations. Because of this, the Drama Lab failed in importing the professionals. The importing and accomodating of a visiting 'star' is a production in itself, requiring the same carefully coordinated promotional campaign needed for the successful play. According to Walt Downs, the production, "Adam's Harvest" with Arthur Franz did not play before large audiences during the three day run at the Sydney Laurence Auditorium. In fact, Mr. Downs remembers that a tense situation existed while Jack quickly raised erough money to honor Franz's contract. 24

24 Interview (tape) with Walter Downs, Mr. Downs' office Anchorage, Alaska. 6 April 1979. 
The fortunes of the Theatre Vorkshop changed when the theatre group lost Don Gretzer, who transferred to Washington D.C. in 1959, and when Frank Brink accepted a position with the Alaska Methodist University in 1960. Gretzer, being a civil servant, was always subject to being transferred by the Government. He had successfully avoided the transfer until late in 1959. 25 Shortly before Gretzer left the State, he and Frank Brink convinced the Theatre Workshop Board to change its name and re-incorporate as the Anchorage Community Theatre Inc. It was becoming clear that the Theatre Workshop's indepenence of the Anchorage Community College was in jeopardy. Without having to pay much rent or other direct facility expenses, the Theatre Workshop was essentially having a 'free ride' and the College was beginning to press for a more binding affiliation. The Theatre Workshop also feared being absorbed, along with its assets and equipment, into the College. Since the show, Arsenic and Old Lace with Boris Karloff in 1957, the seven shows spanning 1957 to 1959 all had made a profit and the Workshop had a substantial balance in the bank. Brink was finding it difficult to avoid the wish of the college's third director, Eugene Short, to absorb the theatre group. Short realized that such groups as the Theatre Horkshop and the Community Chorus offered the best

${ }^{25}$ The civil service tour in Alaska was two years with a "home leave" or transfer to another area at the end of the tour of duty in Alaska. 
public relations the school had at the time. With Frank Brink taking a position on the faculty of Alaska Methodist University, it was unlikely that the Theatre Workshop (now the Anchorage Community Theatre) would stay with the Commity College. The theatre group depended entirely on Frank for its leadership and guidance, especially after Don Gretzer left the State.

Underlying the overall success of community theatre activity in Anchorage during the 1950's was the fact that all performing theatre groups had, or were able to find, a place to play. The facilities seemed to be more available then they are today. There was less competition from other performing arts such as dance and music and the National touring shows had not yet included Anchorage in their circuit.

At the site where the old high school auditorium burned down in 1952, a new municipal auditorium, later named the Sydney Laurence Auditorium, was dedicated in 1955. This facility has about 650 seats. Many people and organizations in Anchorage gave money to aid in this facility's construction. The Anchorage Little Theatre and the Anchorage Drama Lab performed at the Sydney Laurence Auditorium, the American Legion Hall and at the old Elks Hall. The Theatre Workshop used the Romig Hill Auditorium (later named West High Auditorium) exclusively between 1956 and 1960 when the Workshop began to compete for other facilities. The Elmendorf Theatre Guild, of course, had its own theatre facility from 
1955 to the end of their existence in late 1963. At the beginning of the decade, the old high school auditorium at 6 th and G Streets was still in use and so was the old First Presbyterian Church basement in downtown Anchorage. There was an old Railroad building (now a Teen Club operated by the Municipality of Anchorage) on Government Hill, adjacent to the Air Force Base north of the City, which was occasionally used for productions. This facility had a seating capacity of 200 .

The Anchorage Little Theatre gave over $\$ 5,000.00$ to the fund to build the Sydney Laurence Auditorium and apparently took it for granted that they, the A.I.T., would be the resident theatre group using the facility without charge. When the rental policy was established for the auditorium, it was clear that A.L.T. would also have to pay rent, with the one concession that A.I.T. could use the facility rent free for a specific number of shows. 26 The 2,000 seat Romig Hill auditorium was complete and made available for use in 1956. Use of the facility went first to the adjacent high school's schedule, then to the affiliates of the Anchorage Colmunity College, followed by the general public, or non-

26 Interview (tape) with Martha Jo Milliron (formerly Jo Downs), Mrs. Milliron's home, Anchorage, Alaska. 15 August 1977. The number of shows in the Sydney Laurence facility granted A.L.T. rent free is not known. Ms. Miliron's impression is that a period of three years was granted tut this is complicated by the special affiliation with the Parks and Recreation enjoyed by A.I.T. which enabled the group to use the facility at a reduced rate. 
affiliates. 27 By the end of the decade, competition for facilities was becoming a problem. Theatre groups, for example, were no longer able to rehearse solely in the facility they were to perform in. The Theatre Workshop's rehearsal time decreased with each show in West High after 1958. It was becoming necessary to prepare the play elsewhere and bring it into the performance facility shortly.before the show's opening. And the inability to gain a long range facility comitment proved to be an obstacle in the first attempt to develop professional theatre in Anchorage.

A young producer named Barry B. Yellen had succeeded in initiating the San Juan Drama Festival and came to Anchorage in 1959 to look into the feasibility to building a professional theatre company in Alaska. Mr. Yellen felt that in 1959, Anchorage was ready, ". . You don't find many cities of this size with an orchestra, five theatre groups, and a dance company."28 Mr. Yellen's plans were not realized since once again rehearsal and performance space was unavailable for his proposed six week summer season. In addition, local people such as Brink, Mrs. Hale, and others

27 The Anchorage Independent School District, later the Municipality of Anchorage School Board controls the use of the auditorium. The priorities existed until the Anchorage Community College's campus was built in 1969.

28 Anchorage (Alaska) Daily Times. 28 April 1959. The dance company refers to a dance school operated, at the time, by Lynda Lorimore: The Anchorage Civic Ballet was not in operation until 1962. 
teijieved that Anchorage audiences could not support such a season during the summer. This is not to say that some productions had not been successful during the summer, but to produce theatre for six weeks of a relatively short summer was not viewed as sound economics in Alaska at that time. Mr. Yellen wanted the summer in order not to compete unfairly with the very active non-professional programs during the Fall, Winter, and Spring. A factor complicating Mr. Yellen's goal was that the summer was the prime work season in Alaska and for those who did have leisure time, this was the season to be out of doors and out of town. During 1959 there was not enough summer audience in Anchorage and tourism had not yet become a major economic factor. It is also quite probable that Mr. Yellen's proposal, though premature, was threatening to the comunity groups then producing.

Professional theatre failed in 1959 but would be quite successful in 1976. The various non-professional performing groups of the 1950's had a hey-day. There was an abundance of music, dance, and theatre for the Anchorage audience to enjoy. It would be fifteen years before the wave of arts activity equaled that of the period in Anchorage between 1953 and 1960. 
CHAPTER IV

\section{ANCHORAGE THEATRE IN TRANSITION}

In the short span of fifteen years between 1945 and 1960, theatre arts in Anchorage became a vital force in the pattern of Alaskan culture. During this period many changes reflected the development of the community theatre. In the 1960's some of the theatre groups dropped from sight, while others emerged. By late 1963 the Elmendorf Theatre Guild and the Anchorage Drama Lab ceased to exist and the Anchorage Iittle Theatre, which became dormant in late 1961, was revived as the Carnival Civic Theatre in 1964. The Civic Theatre presented theatre programs until May 1974 when it ceased to operate. The Alaska Methodist University's Drama Department, initiated in 1961, was presenting major productions by 1963 . In this sane year the Theatre of Sight and Sound began a program of crafts and music for children. This group presented plays with children in 1967 and by 1969 had evolved into a major community theatre program using adults as well as children. ${ }^{1}$ In 1972 a new group spun-off from the Anchorage Community Theatre and became known as the Anchorage Community College Theatre Guild. In 1976 this new theatre

lplaybill, the Theatre of Sight and Sound's production of My Fair Lady, May 22, 23, and 24, 1975. 
group left the umbrella of the College and became known simply as the Theatre Guild.

When Frank Brink left the Anchorage Community College in 1960 to take a faculty position with the new Alaska Methodist University, the Anchorage Community Theatre split with the Community College as well. Without Brink at A.C.C. the Anchorage Community Theatre opted not to continue its relationship with the College. However, following Brink to A.M.U. and becoming intergrated with the University's Drama Department was not a simple option opened to A.C.T. Although this had been the arrangement between the Theatre Workshop and the Anchorage Community College in 1954, the A.C.T. Board under Frank Brink's influence, was convinced that a home of its own and independence from academy were essential for its development. In view of this, or in spite of himself, Frank Brink found that he was a slave to two masters, the Anchorage Community Theatre and the A.M.U. Drama Department.

In 1964 the extension of the pioneer theatre effort in Anchorage, the Anchorage Iittle Theatre, became the Carnival Civic Theatre. As the Anchorage Little Theatre, the group suffered show losses in 1959 and was faced with selling theatre land in 1960 to pay its debts. Jo Downs, in her search to find new audiences without being burdened with the reputation of A.L.T. changed the name of the group but did not re-incorporate. ${ }^{2}$ She was successful in reactivating

2 Interview (tape) with Walter Downs, Mr. Downs' office Anchorage, Alaska. 6 April 1979. 
the group whose stage presentations had been intermittent between 1957 and 1964. The first presentation from the group under its new name was the comedy, Tunnel of Love by Joseph Field, staged at the Sydney Laurence Auditorium in October of 1964. Although much of the Carnival Civic fare was the musical, Jo Downs tried to offer a varied program that included an occasional drama and comedies as well as the musical review.

In 1966, the Carnival Civic Theatre attempted a particularly ambitious program promoted and funded by Bob Banks, a local night club pianist. This program was to consist of producing a musical a month during a nine month season at Sydney Laurence Auditorium. While Mr. Banks financed the project, as far as it went, he used the Carnival Civic's name and non-profit status. According to Ms. Downs, Banks could not get full advantage out of the Carnival Civic's affiliation with the City's Parks and Recreation Department and therefore had to pay a slightly higher rate for the use of Sydney Laurence than was required of Jo Downs. The arrangement was acceptable to Jo Downs, the group's leader, Ms. Downs, since she could be a part of many of the proposed shows as a performer without the added task of producing and directing. It was agreed that Bob Banks would fulfill these functions. The project, however, was not successful. Mir. Banks was able to stage only two shows, Rodgers and Hammerstein's Oklahoma and Richard Morris' The Unsinkable Molly 
Brown. Banks made a huge profit on the Anchorage production of Oklahoma but loss a considerable amount when he toured the show, by air, to Fairbanks. The project ended when he also lost money on The Unsinkable Molly Brown, a sum which, according to Walt Downs, was in excess of $\$ 7,000.00$. Apparently, Molly Brown was poorly promoted and Mr. Banks tried to present the piece throughout the week, which at the time was not a successful practice in Anchorage. ${ }^{3}$ When Bob Banks left the City Ms. Downs continued to direct and produce about three shows a year. ${ }^{4}$

Probably the most difficult movement to develop in the Anchorage arts has been the children's performing programs. In 1953, during the short lived Alaska Community Theatre project, Frank Brink had envisioned a Children's Theatre as part of the A.C.T. program, and throughout its ten year existence, the Carnival Civic Theatre intermittently sponsored a Youth Theatre program, offering unaccredited classes in acting and music, given by various members of the Civic Theatre. However, the music commity was more successful in keeping a children's performance program functioning with the creation of the Boy's Chorus and the Youth Symphony,

3Most plays in Anchorage prior to 1965 ran for three performances, especially if they were staged in Romig Hill Auditorium. From about 1965 to 1974 a two weekend run was most common. Some musicals ran for three weekends.

4 Interview (tape) with Martha Jo Milliron, Mrs. Milliron's home, Anchorage, Alaska. 15 August 1977. 
both groups continue to perform today. Theatre for children on the other hand, did not enjoy the success of the music groups. The Theatre of Sight and Sound came as close as any theatre group in building a theatre program particularly for children. T.O.S.S. remained solely a children's theatre from 1967 to 1970 . The prime purpose was to provide children's arts activities which were not being provided by other existing groups. 5 In addition a children's chorus, known at the time, as the T.O.S.S. Singers was formed. By 1967, under the influence of Rhoda Fritz and director Jacques L. Condor, T.O.S.S. was producing plays performed by children for the public. Between 1967 and 1969, the group staged five plays. In April of 1969 T.O.S.S. presented James M. Barrie's Peter Pan which moved T.O.S.S. away from children's theatre to the staging of major musicals.

Funding was generated for T.O.S.S.'s early efforts by charging for membership in the group and by fees charged for the classes. Costumes used in performance were the responsibility of the parents of the actors. After 1968 the fees charged were supplemented by grants received from the State and gifts from private donors. By 1970, T.O.S.S. had become a community theatre group in the convential sense, though the productions were restricted to family oriented shows that included children in the performing roles. Among

5nterview with Rhoda Fritz, Anchorage, Alaska. 17 April, 1979. 
the musicals that T.O.S.S. produced were Oliver by Lionel Bart, the Sound of Music by Rodgers and Hamerstein, and 1776 by Peter Stone and Sherman Edwards. From 1967 to 1977 Rhoda Fritz and Jacques I. Condor teamed up to produce and direct the T.O.S.S. productions. After $1977 \mathrm{Mr}$. Condor became involved in staging professional night club reviews throughout Alaska and in the Orient. Mrs. Fritz took leave from theatre activity for other, endeavors.

When the Anchorage Community Theatre left the umbrella of the Commity College in 1960, the immediate project, already underway for the group, was to establish a home of its own. Brink encouraged retired Alaska Airlines President, Raymond W. Marshall, to donate to the theatre group, a two acre lot in the City's southwest section. Finally, in December of 1960 Marshall did donate the land with the proviso that a functioning theatre facility be established within two years.

To flifill the proviso, A.C.T. purchased in 1960 a 50 by 100 foot quonset building package for $\$ 5,200.00$ from the Standard Oil Company. ${ }^{6}$ It was still necessary for A.C.T. to raise a considerable amount of money to construct a basement, erect the quonset shell and to finish and equip the shell for use as a theatre. A subsidy would be needed since A.C.T.'s three or four non-professional shows a year would

GMinutes, Anchorage Community Theatre Board meeting, Anchorage, Alaska. 20 May 1960. 
not support the productions or the expense of the facility. Frank Brink hoped that any money raised to fund the theatre's production program would be in sufficient amounts to support the facility as well.

The Anchorage Community Theatre mistakenly elected to manage and administer its own fund raising campaign. A mail campaign, and a November 1961 Variety Benefit show, failed to bring in a significant amount of money. The President of Anchorage Commity Theatre at the time, R. Everett Harris, announced,". . Quite frankly, we are disappointed by the support thus far. . .but we are touched by the many people who could barely afford the two dollar donations they sent."7 The Building Fund Chairman, James Powers, convinced the A.C.T. Board to take out a bank loan in the amount of $\$ 20,000$ to construct the basement and raise the shell. The A.C.I. Board was divided on the issue to taking out a bank loan. Some members, one being Frank Brink, were against putting A.C.T. in debt. Others on the Board, namely James Powers felt that the risk was minimal since it was not likely that a Bank would foreclose on a theatre anymore than it would on a church when making payments became difficult. ${ }^{8}$ This

${ }^{7}$ Anchorage (Alaska) Daily News, 18 November 1961. There were other monies that came in through the years. By adjusting their assets, A.C.T. qualified and received two matching grants of $\$ 5,000.00$ from the Alaskan based Loussac Foundation.

8A.C.T. paid interest when making the full monthly payment was difficult. The Anchorage Film Society, a part of A.C.T. was doing well with its program and so was able to help A.C.T. in making payments on the bank loan. 
difficulty was anticipated since the problem in raising money through donations was already apparent and the profit margin from shows was small. Mr. Powers assumed that the visual existence of the theatre's shell would make fund raising easier. There was also hope that foundations throughout the country would give to a group which had an existing structure. A.C.T. did not make the two year deadline imposed by Raymond W. Marshall. Nevertheless, Brink convinced Marshall to deed the land free and clear to the theatre group since the purchase of the shell, the land, and the group's history gave promise to the future of the Anchorage Community Theatre. A.C.T. failed in its fund raising because none of the theatre members were professionals at it and resource persons were not locally available. James Powers, A.C.T.'s Building Fund Chairman, was himself a volunteer from the business community and had to ration his own time for the cause. In the early sixties there was no money to hire a fund raiser and no one at A.C.T. undertook the project to seek out the grants as Mary Hale was able to do for the Music Festival during the same period.

The Anchorage Community Theatre quonset remained a shell from 1962 to 1966. In 1966, in anticipation of Alaska's Centennial year, 1967, the Federal Government made special appropriations available to finish, upgrade, and build cultural projects in Alaska. The A.C.T. quonset qualified for such a grant. A little over $\$ 66,000.00$ was granted to finish 
the inside of the empty shell. 9 The facility was used between 1967 and 1974 as a performing arts facility. The Anchorage Conservatory of Dance, a school associated with the Anchorage Civic Ballet, rented a small portion of the basement for its dance classes.

The theatre facility, so long in its acquisition, did not prove a long tern answer for the A.C.T. group. Applications for grants were made in an effort to defray some of the theatre's costs. However, grants were not fundable for facility improvements or payments of outstanding loans. Production profits and rentals, both from the dance school and other producers, did not support the facility. Brink was stretched beyond his capability in managing both the A.C.T. theatre and the Drama Department at A.M.U. Anchorage Community Theatre's program could not operate within its income with the responsibility of the building. It lacked subsidy and full time management. The A.C.T. Board did not see beyond Brink's leadership, which was not available full time. Brink, for his part, continually pointed out as he had done in the forties that his livelihood had to take precdence over his voluntary comitment. This resulted in A.C.T.'s most tragic and ill timed decision in 1974 to seek re-zoning of the property and to place the building up for

9Interview (tape) with John F. Villesvik, at the home of Robert Pond, Anchorage, Alaska. 10 February 1973. The grant was actually $\$ 93,000.00$ but nearly $\$ 27,000.00$ went to administrative and other related expense. 
sale in the early part of 1975.10

Contributing to A.C.T.'s decision to sell its facility was assumption that the group could incorporate its program with that of A.M.U.'s drama department under the common leadership of Frank Brink. Frank remained the dominant force within A.C.T. It was the view of the Board that there was no comparable leader on the horizon. Similarly it could be argued that Frank himself really was not quite ready to relinquish this responsibility. The assumption that both A.C.T. and A.M.U. could benefit by intergrating their programs was, in retrospect, found to be unwise. From 1969 when the Anchorage Community College and the University of Alaska, Anchorage, established a campus next to A.M.U., the problem of A.M.U.'s survival was apparent to most of the community. A student had to pay over $\$ 1,400.00$ to attend A.M.U. at the time, but only $\$ 100.00$ to attend A.C.C. or U.A.A. Beyond the lack of students, A.M.U. was apparently finding it difficult to attract enough endowments and private contributors to meet its operating cost.

The consequence of selling the A.C.T. quonset building became vividly clear when, in 1976, A.M.U. did close its doors and Frank Brink was forced to leave Alaska for his next position. The Anchorage Community Theatre found itself without

10 Once the decision to sell the property was made, A.C.T. actively sought to re-zone the land from unimproved to a business zoning, B-3, making the lot quite valuable. This was accomplished in November 1974. 
a place to perform and without the leadership the group had relied on for over twenty years. James H. Polsky, then President of A.C.T., leased the A.M.U. performing facilities for the 1976-1977 season from the consultant firm which was acting as caretaker of the campus. When A.M.U. reopened its academic program in the Fall of 1977, the new administration viewed the 215 seat A.M.U. auditorium as a prime source of revenue for the still financially troubled school. Accordingly, the university established a high rental rate for the use of the auditorium. ${ }^{11}$

In general, the situation for all the performing arts groups relative to performing space in Anchorage was that there simply was not enough room available for the existing users and their programs. Facilities changed little between 1960 and 1976. There was the West High Auditorium (formerly known as the Romig Hill Auditorium), the Sydney Laurence Auditorium, the A.M.U. auditorium, and in 1976, the 800 seat Performing Arts Center on the Anchorage Community College campus. The A.C.T. quonset, prior to 1974, was available to a limited degree for rental to other arts groups. 12

The 2,000 seat West High Auditorium could not be scheduled before September of the year when the area schools

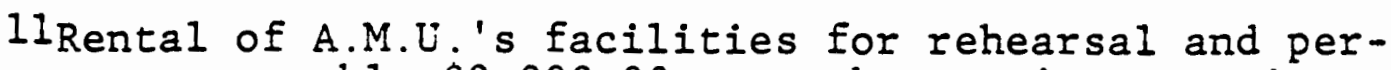
formances were roughly $\$ 2,000.00$ a month, a major cost item for the non-professional arts comunity.

12 When not in use by A.C.T., the quonset was rented to other groups, usually the rate was based on the group's net. 
declared their needs for the facility. By this time, the community groups would have had to have made their decisions and commitments for the performance season. The sydney Laurence Auditorium was also in great demand and the competition for its use was fierce, as it is today. It has to be scheduled a year in advance. In the winter of 1977 when the Alaska Repertory Theatre came into existence, much of the Sydney Laurence Auditorium's schedule became committed to the professional theatre program and thus made the facility much less available for the comminity's use. The 215 seat A.M.U. performing facility was not really available to any significant degree prior to 1976 because of its commitment to the university's use. Similarly, the Performing Arts Center on the A.C.C. campus was mostly taken up with the programs by A.C.C. and U.A.A. ard their affiliates. The time left over for the unaffiliated groups was minimal. The crux of the facility problem in Anchorage from the 1970's on has been that the number of potential users was increasing while the availability of the existing facilities was actually decreasing, given the expanded program of the professional theatre company and the sale of the A.C.T. theatre building.

New performing facilities were not being constructed to meet the community's needs. Other than the Anchorage Community College's Performing Arts Center on campus, completed in 1975, there had been no new facilities built since 1967 when the A.C.T. quonset building was finished. In 1974 a Bond proposal for the building of a Sports-Civic complex was 
defeated. In 1976, a feasibility study by S. Leonard Auerbacin and Associates and commissioned by the City of Anchorage, revealed that the community needed a performance complex consisting of three theatres of varying sizes that was to accomodate much of the music, theatre and dance needs in the commuity. This study did not progress to the stage of being proposed as a bond to the community. Complicating the study's suggested site for the complex was that native Alaskans could, within their lands clains, put claim on the site should the State ever relinquish its jurisdiction. Further, in 1978 a bond proposal for a Civic Center complex in the downtown Anchorage area was very clearly defeated by the tax conscious electorate.

Both the Anchorage Community Theatre and the community's newest theatre group, the Theatre Guild, evolved by using the Anchorage Community College as an umbrella. The Theatre Guild was a spin-off organization of the Anchorage Community Theatre. In the summer of 1968, A.C.T. instituted a workshop called the A.C.T. Guild, in the hopes of attracting more people to the theatre by offering programs of one act plays and scene study. The program was similar to the Theatre Workshop program of 1954 which had enjoyed so much success at the Anchorage Community College. The A.C.T. Guild was intermittent until 1970 when a group under actor Steve Crosby began to produce a series of one acts and scene cuttings for public presentation. In 1972 under the leadership of F. Kenneth Freedman, a theatre instructor at the Anchorage 
Community College, the Guild broke away from A.C.T. and became the Anchorage Comunity College Theatre Guild, operating on the A.C.C. campus. ${ }^{13}$ A local newspaper advertising manager, Paul V. Erown, who had participated in various community theatre productions in Anchorage since 1969, became the A.C.C. theatre Guild's producer. Between 1972 and 1976 the A.C.C. theatre Guild enjoyed a relatively successful period of play production.

Prior to 1976 the Anchorage theatre was administrated by its various director-managers. Frank Brink was the most impressive of this group, having established the initial phase of theatre development in Anchorage. Brink's goal throughout most of his career in Alaska was to establish a professiapal repertory theatre company. He was not able, for all his charismatic personality and talents, to achieve his goal, ". . . My dreams whose dimensions I have never really explained to anyone, were what I felt could be realized with enough faith. But in 1965, they began to die. By 1972 they were gone." 14 Ultimately, Brink's failure to achieve his goal lay in his unwillingness to cooperate with the civic, arts and business

13During Mr. Freedman's tenure at the College, he used the College to foster the Guild's productions rather than to develop a degree program; much like Brink's program at A.C.C. during the 1954 to 1959 period. When Mr. Freedman resigned, Academic Director, Dewey Ehling pushed ahead with a degree program and removed the Guild's umbrella. The degree program could not be accomnodated by the Theatre Guild's goal of community productior:s. 
leaders of the community. He would not share his role as the architect of Anchorage's theatre development.

of the other early director-managers, Jack Wandell was the least organized. He managed his arts affairs on a show to show basis. He was not interested in the long range development of the Drama Lab. After Brink left the Anchorage Iittle Theatre, Shirlie See was a director-manager for the group but she accepted the will of the Board of Directors more than Brink or Ms. Downs. The last of the directormanagers was Jo Downs. Her career in theatre, began in 1955, was largely the product of amateur theatre. Ms. Downs like Wandell, was less concerned over Boards and unlike Brink, strove chiefly to emphasize the show's entertainment value rather than its content. Jacques $I$. Condor, also active as director through the sixties and seventies, was not a director-manager. Rather Conder represented the more recent stage director in Anchorage who does not administer his own group. Mr. Condor was not interested in group development. Paul V. Brown as the administrator of the Alaska Repertory Theatre represents a significant change in the Anchorage theatre. Most of the leaders previous to Brown were volunteer director-managers. Mr. Brown, as a paid professional, became the first theatre administrator in Anchorage when he successfully launched the first professional theatre company in Alaska in 1976. In this capacity he was able to hire his own artistic directors, technicians and professional 
staff. This freed him to spend full time administering his program. The Workshop elected Donald Gretzer as its President. During his tenure with the Workshop from 1954 to 1959, Don's duties included producing and administrating the program. However, in actuality, Gretzer was a volunteer helper while Brink retained the authority over the groups productions and promotional activities. The non-professional circumstance of these two men made it necessary for them to extend their work day to achieve a theatre producing program.

Brown actively developed his talents as an administrator when he discovered producing more rewarding than acting. After some involvement with several commity arts projects beginning in 1969, he joined the A.C.C. Theatre Guild and was partially responsible for their success in play production between 1972 and 1975. He had considerable influence in the rehabilitation of the Sydney Laurence Auditorium in 1974 and the establishment of the "Friday at 8" program which booked in talents both locally and from outside of Alaska, to perform in Anchorage each Friday evening throughout the theatre season. In all, though, Paul Brown's most impressive achievement, thus far, is the establishment of the Alaska Repertory Theatre, the first professioral theatre company in Alaska.

In 1975, Mr. Brown went to work with the Alaska State Council on the Arts on a grant from the Council to investigate the feasibility of professional theatre in Alaska. Predictably, Mr. Brown's report revealed that, ". . theatre 
in Alaska is seriously underdeveloped. . "15 with the acceptance by the State Council on the Arts of his report, Brown decided to develop a professional theatre company from scratch rather than alter an existing group such as the Theatre Guild with which he had worked before. Paul went to the Foundation for the Extension and Development of the American Professional Theatre (F.E.D.A.P.T.) to learn how to accomplish his goal. With the support of F.E.D.A.P.T., the Alaska State Council on the Arts, and private firms, the Alaska Repertory Theatre opened its first season of fully professional theatre in the winter of 1977.

It would be difficult to measure the impact that professional theatre has made on the amatuer theatre programs in Anchorage. In a transitional stage where professional performing arts and non-professional groups co-exist, many adjustments must be made. Although not competing artistically, they have to compete for available facilities, media coverage, and audience support. This has tended to force some groups into a semi-professional status. An example of this can be seen in the structure of the Anchorage Civic Opera. While maintaining the participation of a large number of volunteers, the opera group has increased its paid staff and imports professional talent. This tendency towards professionalism has caused amatuer participants and arts groups some concern

15 Paul V. Brown, "Professional Regional Theatre in Alaska" Report, State Council on the Arts, (1975) p. 25. 
for the continued existence of non-professional theatre in Anchorage. The cost of production has risen far above the point where an Anchorage performing group can expect to cover expenses through the box office receipts. If the non-professional theatre groups in Anchorage such as the Theatre Guild and the Anchorage Comunity Theatre are to survive, a new direction and definition of community theatre will have to be adopted. 
CHAPTER V

CONCLUSION

The mid-seventies brought professional regional theatre to Alaska and the impact of the Alaska Repertory Theatre irrevocably changed the definition of community theatre in Anchorage, Alaska. Along with the Alaska Repertory Theatre, and the semi-professional Civic Opera, the non-professional theatre has had to contend with a municipal orchestra and the Concert Association as well as the Commity Chorus and the university theatre program at the University of Alaska, Anchorage. It is now necessary for community theatre, opera, and music to bid for the limited space, subsidies, and audiences :

The uniqueness of community theatre lies in the fact that neither the professional nor the university theatre programs can completely meet the performing needs of the community. Therefore, this paper deals not with the legitimacy of community theatre but rather how community theatre is to continue to function. To this end, there are three alternatives open:

a. That community theatre evolve into another professional theatre company.

b. That the non-professional theatre attempt to return to a completely volunteer effort, or, 
c. That the community theatre adopt a semiprofessional program, keeping its participants largely a volunteer membership.

It is unlikely that any community theatre in Anchorage could gain the necessary support and finances to rival the Alaska Repertory Theatre in becoming a second professional company for some time to come. Even if it were possible such a move would violate the non-professional's basic reason for existence.

Another possibility for the community theatre in Anchorage is to back away from competing with the professional theatre and opera for the limited space, funds, and audience and become totally a volunteer group, attracting at best a peripheral audience, playing in multipurpose rooms or the like. Again, without funding, this alternative becomes less realistic as the arts in Anchorage continue to become more expansive as well as sophisticated in management practice. Such a grass roots theatre program would have to remain very conservative and limiting in program scope and budget.

The semi-professional alternative appears to be the most realistic direction for the existing community theatre groups to follow. In defining semi-professional, it is meant that while most of the participants would be continue to be non-professional, the group would develop professional management and practices in the search for facilities, funds, and audience. The obvious danger here is that, without care, becoming more professional than amateur seems a natural 
evolution. The Anchorage Civic Opera, for example, will soon face a decision to either allow itself to develop into a professional opera company or to retain its largely nonprofessional make-up.

In adopting the semi-professional direction, the community theatre group must establish itself as a producing organization predictably showing a season of theatre each year. After a season or two of such a program, the group must develop professional management. This must be a paid position (such as an Executive Director) acquired through the existing resources of the group or through a grant.

The professional management, or Executive Director, in community theatre must be someone whose responsibilities and skill include the acquiring of grants-in-aid. Beyond the staffing, fund raising, programing, and the search for facilities, the comunity theatre, through this management, will have to develop a positive relationship with the professional performing community in order to coexist with rather than be threatened by them. The dividends are apparent in the possibilities of mutually sharing resources and talents between programs. The motion of such mutual aid and resource access between the community and professional theatre will be difficult to translate into reality. However fragile such a cooperative relationship may be in the beginning, an adversary relationship would make survival for the community theatre impossible. In this spirit, it will be essential that the 
non-professional and the professional theatres tailor their programs so as to avoid counter-productive conflicts in repertoire and schedules.

For the non-professional theatre in Anchorage, the rules have changed. In losing its ability to be totally selfsufficient as it had been in the first three decades of theatre in Anchorage, the community theatre in adopting the semi-professional procedures and practices will be able to take on projects not previously possible when the directormanager of amateur theatre had to stretch his energies between job, family, and the arts. Whatever the past changes or those that will surely come; the non-prefessional theatre will have to coexist, with professional, each learning and developing from the other. 


\section{BIBLIOGRAPHY}

Anchorage (Alaska) Laily News. 11 May 1953.

" " $\quad 18$ November 1961.

Anchorage (Alaska) Daily Times 15 December 1928.

\begin{tabular}{|c|c|c|c|}
\hline " & " & $"$ & 10 December 1937. \\
\hline$"$ & $"$ & $"$ & 16 December 1938. \\
\hline " & $"$ & $"$ & 18 November 1940. \\
\hline " & $"$ & $"$ & 15 March 1946. \\
\hline in & $"$ & $"$ & 14 September 1946. \\
\hline " & $"$ & $"$ & 12 october 1946. \\
\hline " & $"$ & $"$ & 25 March 1947. \\
\hline 1 & $"$ & $"$ & 1 April 1947. \\
\hline & " & $"$ & 2 April 1947. \\
\hline & $"$ & $"$ & 20 November 1953. \\
\hline & $"$ & $"$ & 28 April 1959. \\
\hline
\end{tabular}

Audit, Anchorage Little Theatre. 27 May 1948.

Brink, Frank 0. Anchorage, Alaska. Interview (tape). 15 March 1973.

Brink, Frank 0. Shreveport, La. Interview (tape). 20 November 1978.

Brink, Frank O. to Robert Pond. 25 March 1979.

Brown, Paul V., "Professional Regional Theatre in Alaska" Report presented to and distributed by the Alaska State Council on the Arts, 1975.

Downs, Walter. Anchorage, Alaska. Interview (tape). 12 July 1977. 
Downs, Walter. Anchorage, Alaska. Interview (tape). 6 April 1979.

Ellana, Iinda. Anthropologist, Unrecorded conversation. Anchorage, Alaska. 20 September 1977.

Forty Ninth Star, (Alaska) weekly, Vol. 30, No. 39. 18 May 1947.

Fritz, Rhoda. Anchorage, Alaska. Interview (Unrecorded) 17 April 1979.

Hale, Mary. Anchorage, Alaska. Interview (tape). 18 July 1977.

Hale, Mary. Anchorage, Alaska. Interview (Unrecorded) 7 August 1979 .

Harrison, Lorene. Anchorage, Alaska. Interview (tape). $18 \mathrm{July} 1977$.

Hulley, Clarence $C$. Alaska Past and Present. Portland: Binfords and Mort. 1970.

Los Angeles (California) Times, "Hedda Hopper" colum. 13 September 1960 .

Meeting: Anchorage Community Theatre Board (Minutes). 20 May 1960.

Meeting: Anchorage Little Theatre, (Minutes). 26 February 1946.

Meeting: Anchorage Little Theatre, (Minutes). 5 March 1946.

Meeting: Anchorage Little Theatre, (Minutes). 8 March 1946.

Memo: Mel Huden, Anchorage Community College, to the Board of Trustees, Anchorage Independent School District, (mimeographed). 15 July 1958.

Milliron, Martha Jo. Anchorage, Alaska. Interview (tape). 15 August 1977.

Playbill: Anchorage Little Theatre production, Our Town. 22 June 1946.

Playbill: Anchorage Little Theatre production, "Bonanza Days". 26 February 1948.

Playbill: Theatre of Sight and Sound (Anchorage) production My Fair Lady. 22 May 1975. 